\title{
2 \\ Technical aesthetics against the disorder of things
}

In March 1964 Dekorativnoe Iskusstvo SSSR published an overview of modern modular furniture. It opened with a description of modern objects' rapid intervention in the home:

The TV set required rearrangement. Turning its back to the light, it oriented the recreation zone around itself. This attracted soft chairs, a collapsible sofa, a coffee table and decorative objects, whereas a dining table, which used to occupy an honourable central place in the room, had to move closer to the wall. Doing so, it did not manage to preserve its round shape and became rectangular.

Despite the centrality of the television, the article's author, A. Piletskii, seemed not to consider it to be an all-important modernising force within the home. Rather, any changes in the home had to be carefully guided by a designer or by a properly informed inhabitant. The rational rearrangement of habitually used objects was only a transitory stage in the development of the home. A modern interior should take the form of a grid on which all objects are placed:

Contemporary cabinet furniture is a well-ordered structure of sectional cases that fills a wall. Regardless of its type (sectional, collapsible or shelves), it has a definite module and rhythm [...] Ceramics, glass, light fixtures, books, prints, souvenirs, plants, fabrics and other household objects infuse this structure, fill it, introduce vibrancy to it; everything ties in a coherent whole. ${ }^{1}$

Hence, while encouraging vibrancy and a certain diversity in the modern Soviet home, Piletskii specified that such diversity should be constrained, subjected to a spatial grid. However, he did not mean that all the objects in a room should be uniform in appearance. In the 'period of the predominance of excess in architecture and furniture' (late 1940searly 1950s), both furniture and brown goods were bulky and ponderous, 
often featuring polished surfaces, and each object demonstrated individual dimensions and finishing. These designs were distasteful, Piletskii argued. With the arrival of modernist aesthetics to the Soviet home in the 1960s, furniture became lighter in terms of weight and colour, and singular objects gave way to complexes of modular furniture - 'a well-ordered structure of sectional cases that fills a wall'. Attempts to subordinate brown goods to modular principles were forlorn, because they remained 'alien' to furniture even when mimicking its external shapes and visual style. As a better alternative, Piletskii proposed the principle of contrast: brown goods should visibly differ from furniture units in terms of shape, material, finishing and colour, manifesting their more unique, interactive character. Yet a grid of traditional household objects and a set of expressive, modern electronic devices should always be balanced. After all, "what is most essential is integrity, interconnectedness and compositional unity. It is not even that important if these are achieved by contrast or by similarity.' ${ }^{2}$

This text illustrates remarkably Soviet design professionals' recognition of the active role of objects in the home. Hitherto unknown objects that differed in their formal and functional qualities, in particular the "newcomers' such as the TV set or vacuum cleaner, forced the inhabitants to think differently about their home and their everyday life. The promise of the Party and government to 'fully satisfy the constantly growing material and cultural demands of the Soviet people ${ }^{3}$ by increasing the quality and quantity of available consumer goods implied the high social and cultural potential of objects. Historians emphasise the government's promise of the proliferation of goods and better homes as one of the key characteristics of the post-Stalin period. ${ }^{4}$ Denis Kozlov and Eleonory Gilburd argue that, in terms of the heightened attention to the living conditions of the now predominantly urban society, the USSR in the 1950s and 1960s was comparable to European countries whose material environment had been severely damaged by the Second World War. ${ }^{5}$ As Kozlov and Gilburd note, 'Unprecedented in the household context, Khrushchev's mass housing campaign belonged with contemporary trends in urban planning, construction technology, welfare and aesthetic vision'. They label the government's effort to reinforce its legitimacy by increasing people's material prosperity and paying greater attention to consumer goods as the 'Soviet regime's new materialism'. ${ }^{6}$ This is, evidently, an ironic allusion to new materialism as a currently popular school of thought that is based on reconsidering the epistemological and ontological premises of conventional social science research.

The full irony of Kozlov and Gilburd's wording is in the strong contrast between the post-war Soviet modernist vision of material culture as manageable through and through, and the new materialist recognition of the agency of inanimate matter. According to Elizabeth A. St Pierre et al., there are many new materialisms practised by scholars in different disci- 
plines, but they are all united by a critique of the foundational assumptions of Western thought, in particular the division between a knowing subject and an inert object, between an exceptional human being and passive matter 'waiting to be acted upon'. ${ }^{7}$ Additionally, St Pierre et al. explain that new materialisms are driven by curiosity and therefore have no definitive methodology - they are 'always being laid out, becoming'. ${ }^{8}$ This methodological fluidity is related to the reconsideration of the doer/deed relationship: "If we take seriously that there is no "doer behind the deed" but that the doer is produced either by or alongside the deed, then the work of method is not completely in our control and must be constantly re-thought and re-claimed in each specificity."

Contrary to this, the 'new materialism' of the Khrushchev government was a policy that favoured belief in the exceptional human being, an expert in urban planning, design and aesthetics, who is capable of organising inert matter into proper socialist objects and furthering rational consumption and daily life. Khrushchev's modernisation campaign left little room for what new materialists call thing-power - 'the strange ability of ordinary, man-made items to exceed their status as objects and to manifest traces of aliveness, constituting the outside of our own experience', in Jane Bennett's definition. ${ }^{10}$ The structure of VNIITE directly manifested the state's will to control, through a network of experts, the totality of things and their influence on consumers. The 'TE' in the institution's acronym, 'technical aesthetics', was promoted as an interdisciplinary science that defined the "laws of artistic activity in the sphere of technology'11 and optimised the production of consumer goods. VNIITE employees, therefore, shared the scientific establishment's interest in cybernetics. ${ }^{12}$ In the Soviet context, this entailed 'the science of managing national planning and economy, administering perfectly calculated goods and services, collecting and interpreting data, and establishing and meeting production quotas'. ${ }^{13}$ Design historian Margareta Tillberg suggests that Premier Aleksei Kosygin appreciated mathematical modelling and computer networks - important components of cybernetics - as tools for increasing the efficiency of the socialist production system without giving way to the evils of the capitalist market. The model of 'industrial cybernetics', developed in the 1950s by Stafford Beer for the steel industry in England, was well known in the USSR through the Russian translation of his 1959 book Cybernetics and Management. Beer's model replaced standard market mechanisms of supply and demand with feedback loops that provided data about aspects such as sales rates, available materials and costs in managing complex companies. Within this model, the Soviet economy appeared 'as an enormous organism that could be optimized by way of computer networks through the channelling and management of information flows'. ${ }^{14}$ This optimisation would further the ordering of material culture. As Diana West argues in her study of Soviet cybernetics, by appropriating this Western 
interdisciplinary science, 'Soviet designers at VNIITE aimed to account for all human physiological and psychological needs in designing a comprehensive system of consumer objects' ${ }^{15}$

This chapter addresses the contradictions of the "new Soviet materialism' by focusing on the work of VNIITE during the initial stage of its establishment. In that period, the institution focused on overcoming what could be called, alluding to Foucault's seminal work, the disorder of things. ${ }^{16}$ Several theorists, referring to Kant's notion of the 'thing-in-itself' and its later interpretation by Heidegger, ${ }^{17}$ distinguish between objects as accessible, instrumental entities, and things as agents of social relations, acting outside human control. Bill Brown asserts that people have ready codes to grasp the meaning of objects and use them without confronting their materiality: for example, we look through windows. However, once objects stop working for us - for example if a window gets dirty - we start confronting their 'thingness', which is not immediately intelligible. ${ }^{18}$ Similarly, Jane Bennett argues that unusable objects, such as those in a rubbish pile, appear as things: 'as vivid entities not entirely reducible to the contexts in which (human) subjects set them, never entirely exhausted by their semiotics'. ${ }^{19}$ Following this conceptual distinction, I suggest that the main goal of VNIITE in the 1960s was to replace the unruly and malfunctioning things that filled Soviet homes or piled up unsold in warehouses with neat, functional objects. The chapter begins with an overview of the genealogy of the key terms that defined VNIITE's activity. Further, it discusses VNIITE's methodologies for studying consumer needs, evaluating already produced objects, and designing new ones. Finally, it presents case studies exploring how these methodologies were implemented in the design of household objects.

\section{Coming to terms with design}

As I demonstrated in the first chapter, the aesthetic turn included a great deal of conceptual and terminological confusion. The idea of a late socialist object and industrial design as a Soviet profession emerged partly because of art theorists' attempts to overcome this confusion. In order to optimise the production of objects, design professionals required a solid, effective terminology. As early as 1955 the critic Moisei Kagan was frustrated that specialists working on furniture, clothes, kitchenware, etc., randomly referred to their own work as 'decorative', 'applied', or 'decorative-applied' art. He insisted that 'decorative art' was the term for decorative elements that have no practical use in themselves (such as decorative vases or wallpapers), while 'applied art' signified practically usable objects. ${ }^{20}$

The need for a clear differentiation gained urgency by the 1960s. Ivan Matsa (Macza János), an art critic of Hungarian origin with experience of the 1920s Hungarian avant-garde, published an article in Dekorativnoe 
Iskusstvo SSSR with the polemical title 'Can the Machine be a Work of Art?'21 Answering this question in the negative, Matsa specified that means of production (machines) can possess beauty but only as a consequence of their technical perfection, not as an intentionally produced quality. Moreover, even though artists sometimes partake in the production process through artistic labour, what they produce are not proper works of art. Household objects, however, including new ones, are made intentionally beautiful and act as 'ideological facts' by expressing certain social values. They, as such, belong to the sphere of art, or, at least, in the category of 'aesthetically meaningful objects'. Matsa's hypothesis implied that refrigerators and cars produced at the same Likhachev plant, for example, were situated on different sides of the divide, whereas refrigerators and porcelain tableware were united by ideological meaningfulness, although the former did not belong to decorative art proper.

Matsa's attempt to draw further distinctions between different kinds of art-like objects was shaky, the argumentation cautious and the overall classification vague. Nonetheless, Matsa called for further work in this direction, seeing these distinctions as crucial for avoiding the 'mistakes' of the 1920s avant-garde:

If one transforms, say, a chair into an object of decorative art, a fabric into a propaganda leaflet, an ashtray into a hybrid of a sculpture and a poster, and interprets a carpet as an easel painting, this, in fact, strongly resembles the unfortunate attempts of those who tried to turn an easel painting into a construction and poetry into the 'literature of facts' [...] Neglecting the specificity of the artistic production of useful objects can not only lead to aesthetic nonsense and tastelessness, but also causes everyday troubles, physical discomfort and the waste of valuable materials. ${ }^{22}$

With the implicit reference to the ideas of Constructivism and the $L E F$ group (particularly the 1925 volume Literature of Facts that included Sergei Tretiakov's article 'Biography of an Object'), ${ }^{23}$ this passage signals not only Matsa's attempt to downplay his avant-gardist past, but also the dialectics of modernism. Matsa accused the constructivists of dangerously mixing things of a different nature at the very same time as the Soviet Ministry of Culture and the official art institutions were preparing a large exhibition in Moscow entitled with the constructivist slogan 'Art into Life'. The avant-gardist urge to fuse art with life that suited the state's campaign to improve the quality of consumer goods and daily life was also accompanied by the effort of professionals to differentiate art from non-art. In fact, productivist theorists such as Tarabukin and Arvatov drew a line between traditional applied art and the 'production art' of the new proletarian society. ${ }^{24}$

Matsa's article proved to be groundbreaking for the aesthetic turn. A month later it received a response from the painter of battle scenes Anatolii Gorpenko, who believed that Matsa had instigated an important discussion 
that facilitated the clarification of 'the basic principles of so-called industrial aesthetics'. ${ }^{25}$ He warned against the limitless expansion of the notion of art and the 'dissolution of art in production', characteristic of the theorists of Constructivism. This dangerous confusion had already been realised, Gorpenko noted, in the 'intentional technisation' of household objects, which often looked like equipment from a technical laboratory. Thus, he did not rush to follow Matsa in calling everyday objects art or at least artish. Besides technics and applied art (understood as traditional household objects endowed with emotional and poetic meaning), Gorpenko distinguished 'a broad sphere of non-artistic production, where an aesthetic factor plays a decisive role'. In this latter category he included such objects as cars, refrigerators, household appliances, radio receivers, standard furniture and even fountain pens. The main criterion for dividing this sphere from applied art was the direction of aesthetic evaluation. In the case of utilitarian everyday objects (predmety shirokogo potrebleniia, literally 'the objects of broad consumption', a standard Soviet expression), we evaluate the object itself rather than its symbolic meaning. Thus, for example, a pair of shoes can be light and refined; the form of a car can be elegant, smooth and dynamic. For applied art (which he occasionally calls 'decorative'), Gorpenko's aesthetic evaluation is directed not so much at the object, as to what this object signifies. Works of applied art 'can be festive or lyrical, emotionally intense, can express different tones and hues of aesthetic feeling, provoke us to imagine the morning freshness of nature, the vivid colours of a sunny day, the spring bloom or the cold magnificence of a winter landscape'. ${ }^{26}$

This approach recalls Nina Iaglova's vision of applied art as essentially representational, izobrazitel'noe'. Unlike utilitarian everyday objects, which all share the same expressive meanings based on their type (e.g. cars express forwardness), each work of applied art reflects the individuality of its creator and his or her 'spiritual constitution' and life-perception. Most importantly, for Gorpenko, the utilitarian function in works of applied art changes by acquiring 'decorative meaning' due to their strong 'semantic and emotional charge'. Utilitarian objects, on the other hand, often have a complicated and self-sufficient technical organisation that does not leave room for emotional expressiveness. This line of argument led Gorpenko to a compromise between an anti-excess modernist stance and a socialist realist insistence on depiction: images and ornaments are welcome in works of applied art, but for utilitarian objects they are inappropriate and excessive. This conclusion, moreover, reveals the different role of materiality in Gorpenko's two spheres. In applied art, symbolic and emotional meanings predominate, whereas the aesthetic value of utilitarian objects resides in their sensory qualities: the 'beauty of the material', the 'elegant and expedient construction'. Finally, at the very end of his essay, Gorpenko claimed that there was no universal working method that could be equally relevant for both spheres. ${ }^{27}$ 
Twelve more opinions followed: the initial discussion about art, machines and aesthetics lasted for almost three years in Dekorativnoe Iskusstvo SSSR. The need for the clear conceptualisation of artistic work in industry proved to be a key question of the post-Stalin aesthetic regime of arts. The philosopher (and future human rights activist) Boris Shragin immediately responded to the Matsa-Gorpenko debate, arguing that aesthetic theory in general tends to fall behind the development of technology and material culture and could not keep up with the rapid changes of recent decades. The result, he argued, was a paradoxical situation: his colleagues could admire machines and practical household objects as human beings, but they vigorously denied this admiration as professionals. In order to catch up with the development of technology, aesthetic theory needed self-criticism and to recognise that its principles should be fluid, socially conditioned and historically changing. Shragin presented the ancient Greek term techne, which referred to all types of creative activity, as useful for describing the material culture of post-industrial societies. ${ }^{28}$

Karl Kantor, a major theoretical contributor to Dekorativnoe Iskusstvo SSSR, objected to Gorpenko's classification, describing materiality as an artistic force that differed from decoration:

simple geometric forms of furniture, the clear rhythm of straight outlines, completeness and coherence between the elements of the form of each object and between different objects (achieved not only by strict calculation, but also by the artist's inspiration and intuition), the clarity of smooth surfaces of ash, covered by transparent polish that does not hide the beautiful texture of the wood, the solidity of planks - all this creates an indelible artistic impression. This simple, unostentatious furniture embodies reliability, restrained dignity, repose and light clarity, which is not the same as the clarity of rational thinking (because it possesses the warmth of vibrant human feeling), but neither is it alien to such thinking. It is good to live with such furniture. It will not oppress, overwhelm, and prevail over a person. ${ }^{29}$

While this passage recalls Aleksandr Chekalov's conceptualisation of vibrancy from 1957 (discussed in Chapter 1), Kantor's argumentation had a practical implication: artists are not only those who work on representational handicraft objects; artists are urgently needed in different branches of industry, from furniture to mechanical engineering. Kantor's belief was that art, understood as the masterful processing of material to shape it into expedient and functional forms through a fine balance of rational thinking and intuition, should be the precondition for comradely, non-oppressive objects. His contribution to the debate implied that applied art has no clear borders.

Similarly, art historian Iurii Gerchuk recognised the aesthetic component in machines and household objects, but expressed uncertainty regarding the relevance of the label 'applied art': notably, he titled his 
article 'The Machine as a Work of Industrial Art' (my emphasis). ${ }^{30} \mathrm{He}$ criticised both Matsa and Gorpenko for drawing borders between art and technics, as he believed that contemporary technological development outran any such borders. Instead of a cosy world of habitual household objects, opposed to a 'cold and somewhat scary' world of technics, there emerged a diversity of objects with different types of beauty and degrees of technological advancement that constitute our everyday experience. He concluded that the recognition of technological progress as an aesthetic phenomenon affected the sphere traditionally viewed as applied art and transformed the appearance of household objects. 'Contemporary applied art' could not exist in the forms produced by handicraft. Thus, the division he suggested was not typological, but chronological: applied art as handmade and ornamental belonged to the past, while applied art informed and reinforced by technological progress was urgently needed by modern Soviet people.

The roundtable, concluding the discussion initiated by Matsa, gathered at the Dekorativnoe Iskusstvo SSSR editorial office at the end of 1963, approximately a year and a half after the establishment of VNIITE. ${ }^{31}$ Evgenii Rozenblium, art director of the 'special artistic-engineering bureau' of the Moscow Economic Council (sovnarkhoz), one of the first regional design institutions in the USSR, enriched the discussion by outlining the nascent theory of design in a socialist society. His colleagues at the bureau had been educated as sculptors, applied artists and architects, and now worked on a broad range of projects, from machines to theatre props. They followed the discussion with great attention, trying to figure out if what they did was art or not quite art: 'A year ago, we were all still creating artworks. And what now? Have we stopped producing them?' ${ }^{32}$ From there, Rozenblium proceeded to raise the problem of the relationship between humans and machines and the problem of style as 'one of the means of technical progress'. ${ }^{33}$ In essence, he delineated the problems that were currently central to the agenda of VNIITE. Additionally, Rozenblium noticed, Matsa's discussion had fulfilled its instigating purpose and had now exhausted its potential. The very notion of applied art had lost its decisive theoretical role.

Since its establishment, VNIITE had avoided the notion of applied art altogether. Drawing on his familiarity with the British experience of institutionalising industrial design, Soloviev and his colleagues faced the task of adapting this concept to the Soviet reality. The Anglophone term 'design' was ideologically unacceptable: Soviet authorities in the early 1960s would not sanction an institution that promoted a 'bourgeois' concept. ${ }^{34}$ However, I suggest that the refusal of the term 'design' was additionally motivated by VNIITE's orientation towards creating clear systems: to combat the disorder of things, a designer first had to eliminate the disorder of terms, which the adoption of the Anglophone word would only exac- 
erbate. A new system of precise terms would also ensure continuity with the earlier discussion among productivists on defining industry-oriented art, thus emphasising the specific character of Soviet design.

This continuity was explicitly stated by the prominent art historian Larisa Zhadova in her talk at the Convention on Artistic Engineering that was organised by VNIITE in Tbilisi in May 1964 and gathered designers from all over the Soviet Union (except for Central Asia where design organisations were not yet established), as well as from Poland, Czechoslovakia, Hungary, East Germany and Bulgaria. ${ }^{35}$ This was, in fact, the first international event for socialist design. Calling for a universal design terminology throughout the socialist bloc, Zhadova searched for its roots in early Soviet Russia. She recalled the imperfect terms of the late 1910s to the 1920s, 'technical art' (tekhnicheskoe iskusstvo) and 'industrial art' (industrial'noe iskusstvo), the former meaning the artistic impact of technical tools and the latter adjusting applied art to industrial technology. A better term, from the early 1920s, 'production art' (proizvodstvennoe iskusstvo), accentuated the 'principal novelty of the nascent phenomenon' and the 'radical shift of aesthetics towards material practice and production'. However, Zhadova argued that in the current situation this term sounded 'naïve, limited and unclear', as 'production' could refer equally to handicraft, workshop and modern industry. It was considered no more relevant in 1964 than the Anglophone 'industrial design', which was criticised as too broad and vague.

For a model of clear and comprehensible design terminology, Zhadova turned to the European countries of the socialist bloc. They were not only the mediators of Western design, but also had their own knowledge on design to share. Czechoslovakia, an industrially developed country with a rich tradition of glassmaking, had attracted Soviet designers since the early 1950s. This interest intensified by the end of the decade, when Czechoslovakia became a popular destination for artists' research trips. ${ }^{36}$ In 1960 Moscow hosted the exhibition 'Czechoslovakia 60', which included work instruments designed by Petr Tucny, the originator of the term 'technical aesthetics' (technická estetika) ${ }^{37}$ In November 1960 the USSR Ministry of Higher and Vocational Education sent a group of artists, architects and engineers of different profiles, as well as economists and linguists, to learn from Czechoslovak industry, design, art and pedagogy for a year. ${ }^{38}$ Aleksandr Korotkevich, the head of the Department of Industrial Art at MVKhPU, participated and was impressed by Czechoslovak designers' engagement in the mass housing campaign and industrial production of goods. He specifically noted 'the science of industrial aesthetics' promoted by Zdenek Kovar, professor of the Prague Institute for Arts and Crafts. Simultaneously, Tucny accepted an invitation to take a short-term job in Moscow. In cooperation with the construction bureau of the famous aerospace engineer Andrei Tupolev, he designed a number of machine 
tools for the aviation industry. ${ }^{39}$ This is how Tucny's 'technical aesthetics' was planted in Soviet soil, although in a distorted form. While Tucny used 'technical aesthetics' as a theory for improving the conditions of industrial labour through ergonomic machine tools, Soviet designers interpreted this term in relation to the design of both capital goods and consumer goods. ${ }^{40}$

The Czechoslovak import of still unstable terms, coupled with diverse interpretations of them in the Soviet design community, created a logical confusion, further intensified by the chaos of definitions for artists working in industry in cooperation with other specialists. The situation resembled the earlier search for proper terminology among industry-oriented artists in the late 1920s, when such terms as 'artist-constructor', 'constructivist', 'artist-technologist', 'engineer-artist' or even the cumbersome 'engineer-artist-constructivist' were used at different moments and in different settings. ${ }^{41}$ Although Zhadova admitted at the 1964 Tbilisi convention that a 100 per cent stable terminology was impossible, she offered a conventional scheme, systematising the terms that had already been in circulation for a while: 'the new sphere of artistic creativity is industrial art [promyshlennoe iskusstvo]; the method of practical fulfilment of the task of industrial art - artistic engineering [khudozhestvennoe konstruirovanie]; 42 the theory of industrial art - technical aesthetics [tekhnicheskaia estetika], and the new type of artist, different from applied artists and decorators - artist-constructor [khudozhnik-konstruktor]'. ${ }^{43}$ This terminology was officially accepted, even though the implications of each term continued to be debated, specified and expanded on at professional meetings and in Dekorativnoe Iskusstvo SSSR throughout the 1960s and after, until the Anglophone terms dizain and dizainer were officially accepted in the mid1980s. Thus, coming to terms with the avant-garde legacy alongside the Western model and with the experiences of their East European socialist colleagues, Soviet designers outlined a contemporary way of speaking about their profession and a terminological toolkit to solve concrete tasks more effectively.

\section{Managing the chaos of forms}

Armed with a clear system of terms, VNIITE specialists confronted the disorder of things that plagued Soviet industry and trade. As they stated in a 1965 report on current production, the variety of Soviet goods "is not based on the advantages of the socialist economic system and, instead of producing a limited, optimal assortment of high-quality goods, we produce many defective objects that duplicate each other'. This approach, the VNIITE designers believed, was characteristic of capitalist countries and therefore alien to the USSR, and it could bring 'serious economic, ideological and political costs'. ${ }^{44}$ 
Indeed, socially oriented Western designers of the post-war period criticised the chaotic flow of mass-produced goods. Their search for comprehensive and responsible standards became central to the work of organisations such as the British CoID and was an important objective of the 'good design' movement. ${ }^{45}$ The disorder in the material environment in industrialised societies was on the agenda of the 1963 ICSID congress in Paris $^{46}$ - Rozenblium called it a 'chaos of forms' ${ }^{47}$ Notably, according to the design historian David Raizman, this disorder was perceived in connection not only to the market but also to totalitarian ideologies: 'Shared standards and limits to the expressions of individual will, whether in product design, graphic design, or political or moral attitudes, were viewed as bulwarks against manipulations by advertisers or demagogues, especially in an age of mass communication and amid lingering fears of totalitarianism. ' ${ }^{48}$ It is possible to argue that VNIITE professionals, too, devised technical aesthetics as a stronghold against the arbitrary tastes of political leaders as well as managers in industry and trade, keeping in mind the exuberance of Stalinist architecture and interior design. Being a part of the aesthetic turn, technical aesthetics considered the needs of ordinary people instead of glorifying the state and Party leaders. As Soloviev explained, this young scientific discipline 'represented consumers' interests in production'. ${ }^{49}$ In this respect, VNIITE followed the lead of post-war Western advocates of modern design in striving to serve public interests..$^{50}$

For VNIITE designers, however, the main obstacle was not the deliberate manipulation of consumer interests for political purposes, but a rigid planned economy focused on quantity rather than quality. As designers unceasingly emphasised, newly built flats not only often had poor layouts, they were difficult to properly furnish and make comfortable. ${ }^{51}$ The enterprises that produced household objects were blamed not so much for insufficient production as for the lack of coordination and the resulting excess and chaos of products. Generally, goods of the same type (such as refrigerators) were produced by several factories that were answerable to different ministries. These models closely resembled each other and were often, as designers painfully noted, obsolete. As such, demand for them lessened over time and unused, obsolete products filled Soviet warehouses. A related problem was that available household goods of different types and categories were often stylistically discordant. Therefore, people could not get proper furnishings for their homes not because of insufficient production, but because of an excessive variety. In the very first issue of Tekhnicheskaia Estetika, the economist Iakov Orlov presented this problem as evidence of 'the lack of integral technical and aesthetic policy'. ${ }^{52}$

Claiming that the chaos of forms vitiated the advantages of a socialist economy, which was meant to produce a powerful alternative to capitalist consumer culture, Soviet designers also admitted that Soviet goods were significantly poorer than Western ones. VNIITE reports explicitly stated 
that Soviet consumer objects were pale analogues of Western goods. In one 1965 report, the ergonomic factor was cited as playing an essential role. For example, the electric shaver Utro, designed entirely by engineers and produced by one factory under the oversight of the Leningrad Economic Council, had a handle with a small diameter, similar to a screwdriver or an awl. The use of such tools presupposes a direction of force along their axis, whereas shaving requires the sliding of the shaver's head over the skin, for which a tool-like handle is unsuitable because the holding hand is in a horizontal position. VNIITE designers characterised this shape with the colloquial term neprikladista - literally 'non-applicable'. The best translation may actually be 'not user-friendly', though it does not indicate the sense of touch as much as the Russian original does. In contrast, the Milward Courier, a British shaver designed in 1961 by Kenneth Grange for Henry Milward \& Sons, was praised as well shaped to the specific hand movements of the shaving process, or prikladista - user-friendly.

The British shaver also seemed superior because of its ease of maintenance: it came with a knife for cleaning the cutter screen, while the Soviet shaver's design made cleaning more complicated. The Milward Courier also had a power button located under the index finger that prevented the user from accidently turning the shaver off, as could easily happen with the Utro. Even the case of the British model impressed Soviet designers, as it was light, elegant and precise in holding the shaver, while the Soviet one looked more like a camera case and was unrelated to the actual shape of the shaver. VNIITE's analysis concluded that the Utro was disappointing, while the Milward Courier demonstrated 'high aesthetic qualities', harmoniously combined with 'convenience of use, logical and simple construction and, simultaneously, technological excellence': in short, it 'united the qualities that constitute the basis and principles of artistic engineering'. ${ }^{53}$ Thus, while insisting that the socialist economic system was the only precondition for proper 'artistic engineering', VNIITE found its ideals in 'capitalist' objects. This was a necessary compromise. A similar conclusion resulted from the comparison between Western and Soviet vacuum cleaners, hot plates and other household objects. ${ }^{54}$

This was not a naïve lament over the disappointing, deficient objects still sold in a country that anticipated the arrival of full-blown communism in less than twenty years. The VNIITE report, like several articles in Tekhnicheskaia Estetika, offered a precise list of causes for the disorder of things: a lack of scientifically justified variety in consumer goods; the poor development of consumer opinion research; a disregard for technical aesthetics by the State Committee for Standards; a lack of design services at the majority of enterprises producing consumer goods; a lack of coordination between the trade shows and the work of economic councils on approving new prototypes for consumer goods. The report went on to give a list of recommendations that included an urgent call to create optimal 


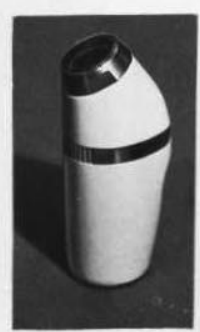

СРАВНИТЕЛЬНЫИ АНАЛИЗ АНГЛИЯСКОИ БРИТВЫ "МИЛВАРД-КУРЬЕР" И БРИТВЫ "УТРО-1"П П/я $N 468$

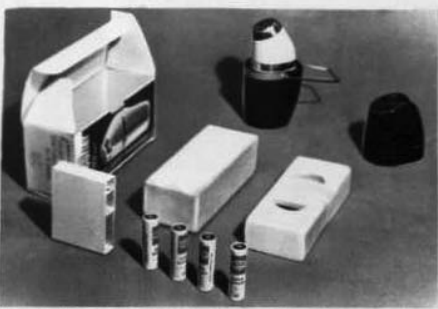

Pис,1. Упаковка элегантиа п् удобиа. Она coor ветствует форме пзделик.

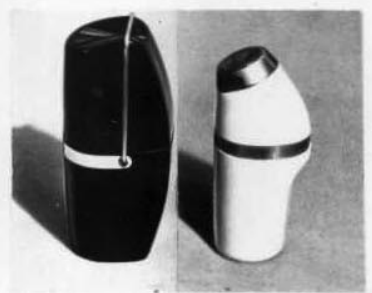

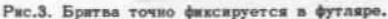

Pmс,4. Kopmyc бритвы хоромо пежат в руке, Поворот головки под углом удобен дли положения руки,

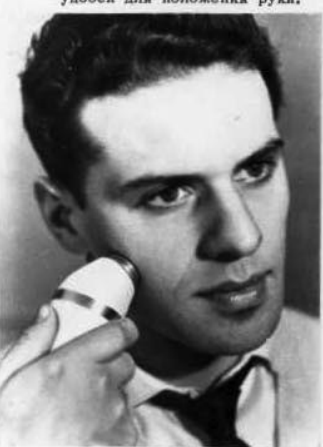

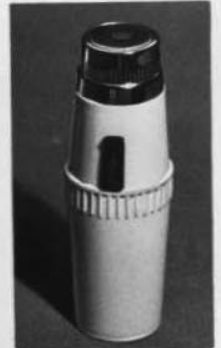

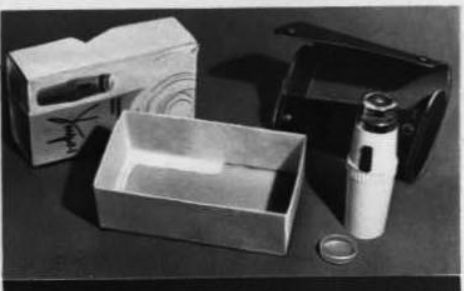

Pнс.2. У паковка совершенно не свизана

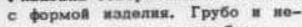
psimano numomena ropo6xa.

Pис.5. Держать бритву неудобно, рука прі этом паходится в горшзонтальном положенгв,

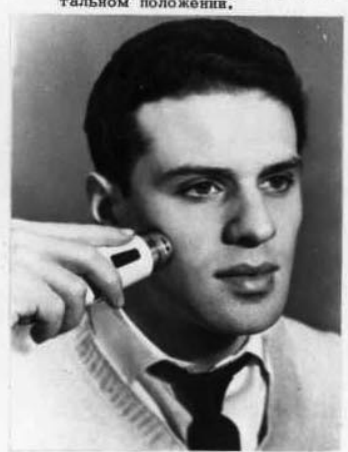

All rights reserved and permission to use the figure must be obtained from the copyright holder.

2.1 Comparative analysis of British electric shaver the Milward Courier (left) and Soviet analogue Utro (right), 1965. 
varieties for different types of consumer goods; the development of norms and standards for consumer products informed by technical aesthetics; the abandonment of all existing systems for the approval of new prototypes in favour of a new, quality-oriented system; and placing greater responsibility on the heads of enterprises who gave final approval. The report also advocated direct agreements between industries and trade organisations and the establishment of a permanent exhibition of approved prototypes that would showcase them in clear arrangement according to their types: thus, shavers, for instance, produced by different factories, could be easily compared when juxtaposed with one another. This universal exhibition would be subject to regular inspections by an expert committee that would remove exhibits found to be irrelevant to consumer needs. The show would be open to the public and be used to research public opinion. ${ }^{55}$

From 1965 Brezhnev-Kosygin's recentralisation of Soviet planning meant that the task of policy integration and production control became even more acute. In a 1966 article, the architect Aleksandr Riabushin, employed in the VNIITE department for the design of household goods, called for rigorous scientific methodologies for the regulation (uporiadochenie) of production, without which any discussion of stylistic unity would be impossible. Anticipating the objection that standardisation contradicts consumers' interest in limitless diversity, Riabushin drew a distinction between the terms nomenklatura (typology) and assortiment (varieties), the former understood as the typology of goods and the latter as the total sum of produced goods. Ideal types of the nomenklatura would therefore constitute a harmonious order that would then be embodied by sensible and tangible models of the assortiment. While nomenklatura, Riabushin believed, would help rationalise production and modernise mass housing, assortiment would encompass the variety of consumer tastes. ${ }^{56}$ The next logical step would be the total regulation of the material environment, which was indeed the major objective of VNIITE in the second half of the 1960s. Major proponents of this totalistic vision of design were Riabushin and the philosopher Karl Kantor, as well as the philosophers of the Moscow Methodological Circle, headed by Georgii Shchedrovitskii, who joined VNIITE in 1965. The Circle's critical approach to systems theory in its Western variants and methodological understanding of all kinds of activity resonated with technical aesthetics' aspiration for the status of a universal science of design ${ }^{57}$ This ambitious task required a system of clear algorithms: for studying consumer demand, evaluating currently produced goods, and for designing new objects that would comprise perfect order.

\section{What 'people's needs' exactly should designers satisfy?}

A crucial measure for combating the chaos of forms was to strongly connect production plans to consumer needs. In the late 1950s and early 
1960s, informal research on consumer demand was carried out through shoppers' conferences, complaint books that were mandatory for all shops, and letters to popular magazines. ${ }^{58}$ In 1960 the Institute of Public Opinion emerged at Komsomol'skaia Pravda, the official newspaper of the all-Union Soviet youth organisation (Komsomol). This was not a government initiative, but a grassroots one by the newspaper's editorial board, which consisted of philosophers and journalists. ${ }^{59}$ The Institute's second opinion poll in 1960 concerned the 'dynamics and problems of standards of living in the country' and was logically bound to the topic of consumption. According to the Institute's founder, the philosopher Boris Grushin, the four earliest polls lacked a clear scientific methodology, were not at all representative for various social groups throughout the country, and had to comply with the newspaper's ideological guidelines. ${ }^{60}$ However, the Institute achieved a higher polling standard from 1961: it developed more representative samples, better systems for coding, and provided better preparation of interviewees and coders. As a result, the Institute's findings entered scholarly sociological publications beginning in 1962. Around the same time, the newly established VNIITE involved Komsomol'skaia Pravda's Institute in preparing a questionnaire on domestic radio and TV equipment. This was a part of the designers' project to study consumer demand for 12 groups of consumer goods considered the most socially and economically significant. Relying on methods developed by American sociologists such as William J. Goode in the 1950s, ${ }^{61}$ the researchers from the two institutes structured the questionnaire around various consumer groups. Each group was defined by the following characteristics: living conditions, income, family size, type of settlement, occupation, 'cultural level' (education and aesthetic sensitivity), age and national traditions (gender was conspicuously absent from their study) ${ }^{62}$ The results of the questionnaire revealed significant dissatisfaction with currently available goods in terms of appearance, performance, size and ease of use. According to a senior VNIITE researcher, these findings would help designers improve the typology of radio devices and provide trade organisations with recommendations for a more rational distribution of commodities throughout the country in accordance with actual consumer preferences. While the report on the initial stage emphasised the danger of 'blindly following' consumer demand and the necessity of educating consumers about taste, it nonetheless described the designers' awareness of consumer demand as a crucial aim of technical aesthetics. ${ }^{63}$

The joint research by VNIITE and Komsomol'skaia Pravda's Institute was a response to government discussions on the necessary measures for the systematic study of consumer preferences. A proper research institute for precisely this purpose was organised in June 1965 under the auspices of the USSR Ministry of Trade (abbreviated as VNIIKS). ${ }^{64}$ Its tasks included studying consumer needs, developing precise methods for 
monitoring and predicting them, and presenting the research outcomes to trade and industry. Regional branches of VNIIKS appeared in 150 Soviet cities. ${ }^{65}$ Local shops and warehouses, which monitored consumer preferences through conferences and exhibitions of goods, assisted VNIIKS branches. ${ }^{66}$ While VNIIKS was beginning, a group of socio-economic researchers at Department No. 8 of VNIITE (which dealt with consumer product design) prepared a precise methodology for consumer research, aiming to advise special artistic-engineering bureaus and designers at factories under VNIITE's supervision. This methodology would be a necessary guide for designing any new object. Trade organisations, too, would need to rely on this methodology in their investigation of consumer preferences because their currently used methods were, according to the VNIITE group, poor (for example, questionnaires were inconsistent and included vaguely formulated questions). ${ }^{67}$ Instead, the designers suggested a concrete yet flexible methodology that did not aspire to be the ultimate source of information on consumer preferences (and which could be combined with other sources, such as statistics on marketing) and recognised the fluidity of the category 'consumer group' ('they can change, transfer from one type to another, or disappear'). ${ }^{68}$ According to the institutional report, this was the first comprehensive, theoretically informed and practically useful methodology for studying consumer demand in the Soviet Union.

The concrete methods the designers proposed can be summarised as follows. A necessary preliminary step was the collection and analysis of data from statistical institutions, trade organisations, wholesale fairs, shoppers' conferences and the press. The next step would include different types of polling: questionnaires with open and closed questions, interviews and panel surveys, as well as distributing new models of goods to small groups of consumers for temporary use. The results would be translated into computer coding at so-called machine-calculating stations, expressed in percentages and arranged in correlation tables. From there they could be examined along with the quantity of production of consumer goods and analysed with different consumer characteristics in mind (age, gender, occupation, etc.) and arranged again in 'tables of preferences'. This analysis would then be used to determine consumer tendencies and, ultimately, establish a universal system of guidelines for all Soviet design organisations. ${ }^{69}$ Thus, VNIITE took what was conventionally called the 'constantly growing material and cultural demands of the Soviet people' very seriously. A diversity of needs, processed, systematised and comparatively analysed, would become an instrument for ordering things. As the report explained, consumer research was the necessary foundation for designing 'objects with a definite aim' (predmetov s opredelennym adresom) rather than 'objects as such' (predmetov voobshche).${ }^{70}$ Objects that responded to specific, carefully examined needs would not end up 
unused in warehouses. In this way the VNIITE research group resolved the contradiction between the state's promise to satisfy consumer needs and the design experts' urge to teach consumers good taste: popular needs, organised through a clear taxonomy, would become the guidelines for intelligent and rational consumption.

As an example, the report included a poll about household appliances, aimed at optimising the varieties of this type of household objects. The poll, consisting of five multiple-choice questions on preferred types of appliances, their quantity per household, and the type of domestic labour that most needed mechanisation, was published on 25 July 1965 in the newspaper Nedelia (Week), a daily appendix to the official government periodical. The poll was far from representative; only 1,751 people participated (though they answered on behalf of their families), predominantly technical specialists and civil servants. However, it signified an important move towards giving consumers a say in the design of the objects they used every day. ${ }^{71}$

\section{Evaluating objects}

Consumer research allowed designers to decipher consumers' requirements for commodities to a certain degree. According to technical aesthetics, these requirements predominantly defined quality. The Department of Engineering Evaluation at VNIITE promoted quality as 'the reflection of the level and character of the requirements' given to an object, rather than the result of this object's natural characteristics. In evaluating prototypes or already produced objects, designers should first of all determine the degree of correspondence between 'the interest of a person as a consumer and the interests of society as a producer' ${ }^{72}$ Thus, technical aesthetics presented quality as an indicator of an object's social function: harmonising the relationship between the individual and socialist society.

Expert evaluation (ekspertiza) was a significant part of VNIITE's work and a necessary complement to design. Its three major goals were to inform industries about the adequacy of their current products in relation to the requirements of consumers; to define the principles of technical aesthetics in product design; and to further the rationalisation of varieties of goods. In short, expert evaluation was a cornerstone of the process of ordering things. In its manual for the expert evaluation of industrially produced objects, the Department of Industrial Evaluation at VNIITE admitted that determining quantitative measures for product quality was still a work in progress. However, they believed that a combination of sociological research, laboratory and in situ testing, consultation between different specialists, and the designer's artistic intuition would provide a good basis for the expert evaluation of products even in the absence of a rigid quantitative methodology. ${ }^{73}$ 
For a non-quantitative evaluation, the VNIITE guidelines suggested 'generalised quality criteria' conventionally divided into sociological, operational and aesthetic aspects. Each aspect presupposed a specific set of questions. For each specific object and for each type of expert evaluation a different set of questions would be of major importance.

The first group of questions concerned the social characteristics of an object: how necessary is the object for fulfilling a social need? If it is an object for personal consumption, how does it compete with public services for satisfying needs, how does it further the development of these services or rationally complement them? The question about the object's ability to satisfy specific needs no less adequately than public services is particularly notable. This formulation suggests a compromise between the collectivisation of everyday life, revived from the 1920s and conceptualised by the Party as 'service in the culture of daily life', and the large-scale building of individual family flats with furnishings that made domestic labour more convenient. According to the Third Party Programme, adopted in 1961, the development of more home appliances to ease housework (especially for women) should be a temporary measure before the full switch to "public forms for satisfying the material-everyday needs of a family'. ${ }^{74}$ In 1966 urban planning organisations in Moscow estimated that institutions such as public canteens, laundries, repair stations, nurseries and kindergartens would double in number in the capital city by $1969 .{ }^{75}$ Yet VNIITE designers were cautious about dismissing the importance of commodities for individual homes. In the introduction to the aforementioned 1965 poll, the design team from Department No. 8 admitted that, however important the development of public services was, they would not suit everyone universally and it would take time before many people could get used to them. The switch to public services would not eliminate the problem of keeping the home tidy, and cleaning services who came to flats would need customised appliances. In addition, home cooking was considered a pleasure in its own right (though the VNIITE guidelines present it as one specific to housewives). ${ }^{76}$ Considering the development of housing and urban planning in the 1960 s, the position of a commodity in relation to the material structure of public services was a significant evaluation criterion for VNIITE experts. Consumer opinion research played an especially important role in this part of the evaluation.

The second set of questions in the 1967 VNIITE guidelines related to the technical and operational aspects of goods' quality. These were categorised within three different relationships: object-person (questions of safety, ergonomics, hygiene, durability, psychological effect), object-object (the object's role as a tool for maintaining another object, as in the case of a vacuum cleaner and a carpet) and object-environment (the choice of materials, the interaction between several related objects, the problem of storage and climate conditions for the object's function- 
ing). This part of the evaluation required a particularly interdisciplinary approach involving different specialists - engineers, technicians, psychologists, physicians and economists.

Finally, the third group was comprised of questions on the aesthetic effects of an object on both its producers and its consumers. In the case of producers, the aesthetic effect was presented as a producer's emotional satisfaction with the harmonious proportions of an object, the rational choice of materials, convenience of assembly and operation and the clarity of the smallest details. The aesthetic feeling of a producer was described as being determined by the labour process. When it came to a consumer, the VNIITE manual recognised two components of an object's aesthetic effect. The first was a by-product of the object's social significance, functionality, user-friendliness and the quality of its construction (konstruktsiia, a term borrowed from 1920s Russian Constructivism meaning the essential and sufficient structure of an object). The second component of an object's aesthetic effect was an elusive 'artistic fullness' (khudozhestvennaia polnotsennost) with no definition. Both the producer and consumer based their aesthetic evaluation of an object on 'subjective judgements about the object's objective characteristics'. The consumer's evaluation depended on his or her social status and preferences (the manual gave no similar specification for the producer).

This sophisticated guidance for expert evaluation required interdisciplinary cooperation between the designer, engineer, ergonomics specialist, sociologist, technician, medical expert and economist. The result of the evaluation, if successful, would reveal the interrelations and coherence between an object's different characteristics. ${ }^{77}$

In practice, however, some of the stages or aspects of an evaluation could be skipped, depending on the character of the object in question. For example, in its evaluation of domestic tape recorders produced in the USSR in 1966, the same Department of Industrial Evaluation provided a detailed evaluation of their technical characteristics, but barely approached the social and aesthetic aspects of the objects. ${ }^{78}$ Obviously, in the mid to late 1960s, ordering things was still a work in progress: a painstaking, sophisticated project, riddled with vague concepts and technical and organisational discrepancies. Therefore, evaluation guidelines produced by VNIITE at this time demonstrate on the one hand a striving for clarity and, on the other, a tendency for excessive, even messy, specifications.

\section{Artistic-engineering elaborations}

The guidelines for designing new consumer goods at VNIITE were called 'artistic-engineering elaborations' (khudozhestvenno-konstruktorskiie razrabotki, KhKR for short). In the Leningrad branch of VNIITE (LF VNIITE), 
the enthusiastic researcher Vsevolod Medvedev took the lead on KhKR. He presented a detailed algorithm for KhKR in 1966 with four major stages: first, research into the sociological literature on consumption, foreign product models, existing varieties and consumer demand; then, sketch designs (eskiznoe proektirovanie), accompanied by consultations with customers and relevant experts; next, technical design (tekhnicheskoe proektirovanie), that is, figuring out the details of objects and preparing sketches and mock-ups for discussion at VNIITE's artistic-technical council and subsequent demonstration to the customer; and, finally, the mass production of the designed object. ${ }^{79}$ While this algorithm included multi-level analysis of technological, functional, economic, ergonomic and aesthetic factors, user preferences were conspicuously absent. As a prominent Leningrad VNIITE designer, Mikhail Kos'kov, later commented, in KhKR 'a human being was considered in the tradition of functionalism: first, predominantly from an engineering, rationalistic point of view, ignoring their personal, spiritual needs, and, second, on average, as a person fitting into norms' ${ }^{80}$ This was not a specifically Leningrad feature: as Diana West has demonstrated, human agents appeared as little more than extensions of rational systems or were altogether neglected in many Soviet design projects of the 1960s and later. ${ }^{81}$ The Soviet order of things envisioned in the 1960s, therefore, neglected not only thing-power - the force of things beyond human comprehension - but also the individual agency of a consumer, notwithstanding the official rhetoric about 'satisfying the constantly growing demands' of people.

In terms of the concrete application of KhKR, one of the major works of Leningrad VNIITE was the design of standard sets of kitchenware for the model flat, worked out in 1965-66 by Moscow VNIITE in collaboration with the Central Research and Project Institute for Housing and Public Buildings and other construction institutions. ${ }^{82}$ This project demonstrates the Soviet aesthetic regime of arts: a seemingly banal theme, kitchenware, was one of the entries for the Soviet Union in the international debate concerning modernity. Recent scholarship has revealed the kitchen's critical role in the history of the twentieth century: as a laboratory of modernisation, a showcase of advanced technology and consumption, a space for embodying gender stereotypes, and a battleground of economic systems and ideologies. The debate between Nikita Khrushchev and US Vice-President Richard Nixon in front of General Electric's model kitchen at the American National Exhibition in Moscow in 1959 has become an iconic image of the Cold War. ${ }^{83}$ In a special volume devoted to mid-century kitchen design, Ruth Oldenziel and Karin Zachmann presented the kitchen 'as a complex, technological artefact that ranks with computers, cars, and nuclear missiles', and more specifically, as 'the sum total of artefacts, an integrated ensemble of standardised parts, a node in several technological systems, and a special arrangement'. ${ }^{84}$ In Soviet society under 
Khrushchev, the modern kitchen was an integral part of the mass housing campaign and the site for implementing promises on technological progress and material abundance (the Moscow Pioneer Palace, discussed in Chapter 1, included a modern kitchen where girls were trained in housewifery). According to the results of a questionnaire conducted by the central VNIITE in 1965, cooking was the most time-consuming burden on Soviet housewives, and it was expected to be mechanised first of all. ${ }^{85}$ While utopian visions of the total collectivisation of cooking and dining, echoing those of the 1920s, appeared in the press, ${ }^{86}$ a housewife's labour in the kitchen - now increasingly more often an individual, rather than communal, kitchen - was a ubiquitous reality. It needed to be maximally rationalised and automated, and, accordingly, the kitchen was presented in popular journals and household literature as a modern workshop, akin to the site of industrial production. VNIITE took the kitchen of a prefabricated flat as a proper testing ground for ordering things.

The Leningrad design team, headed by Medvedev, painstakingly passed through the three stages of the KhKR of kitchenware typology. First, they examined the latest Western literature on household management and kitchenware models (mostly British, French and West German sources), opinion polls undertaken by trade organisations, and the variety of kitchenware previously developed by the Central Research Institute of Housing (TsNIIEP zhilishcha), as well as the (uncoordinated) kitchenware production of Soviet factories. Second, on the basis of this research and consultation with an economist and art critic, Moisei Kagan, they created a typology of dimension-types (tiporazmerov) of kitchenware objects. ${ }^{87}$ Third, they prepared detailed technical drawings and mock-ups with an eye to the current and potential production of relevant materials. This KhKR was focused on a kitchenware set for a family of 3-4 people, which was to complement a particular project for a kitchen furniture set, run in parallel at Moscow VNIITE. One set was made from polished aluminium, another from enamelled steel. According to the KhKR report, the kitchenware would fit the kitchen furniture perfectly so that space in the kitchen would be used effectively. Contrary to the conventional classification of kitchenware that was based on the type of material and the technology involved in production, Medvedev's team used a classification based on the specific labour processes in the kitchen, such as washing and cutting foodstuffs, different methods of cooking (boiling, frying, steaming, baking, etc.), and the storing of food. For the sake of space (and of course raw materials used in production), designers proposed multi-purpose pots into which different pannikins (vkladyshi) could be inserted for preparing different meals or boiling milk. All the modelled kitchenware had rational, concise forms, with functional details embodied in decorative elements. In the aluminium set, all of the lids' surfaces were heat-protected and decorated with colour anodising. This method followed Western examples 


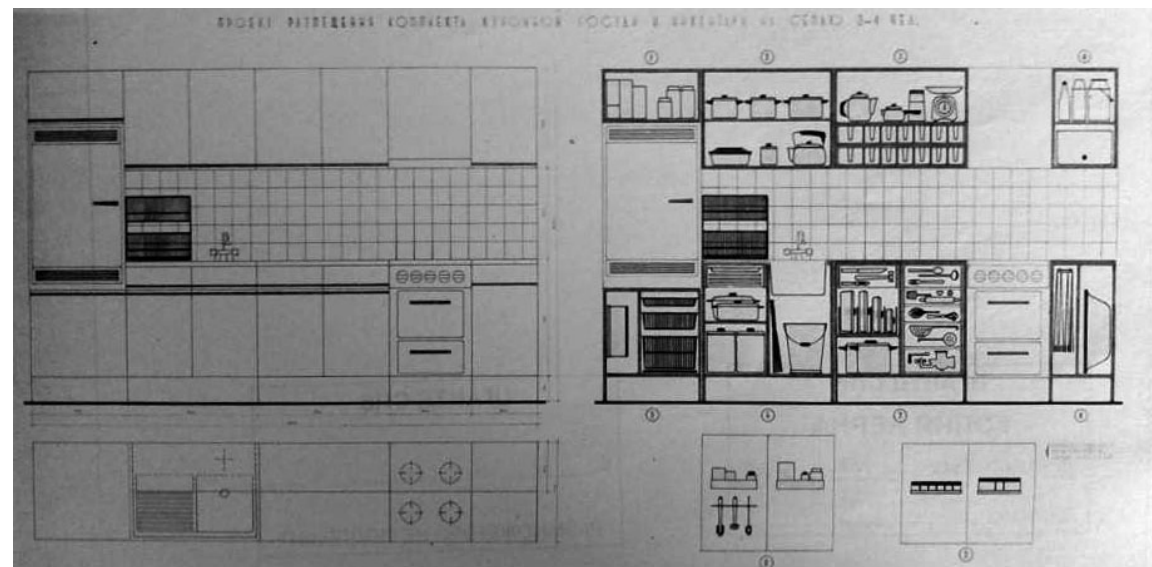

All rights reserved and permission to use the figure must be obtained from the copyright holder.

2.2 Vsevolod Medvedev et al., project for an array of kitchenware and implements for a family of 3-4 people, 1966.

and would have been an innovation in the USSR. Suggesting various colours for anodising - from yellow to turquoise - the designers argued: 'The addition of colour to the cold surfaces of polished ware, emphasized by the black spots of [plastic], significantly enriches its liveliness.' ${ }^{88}$ This solution would meet consumer demand for 'bright and trim kitchenware', as indicated by opinion polls. Another technical innovation with decorative effect, chromium-plated polished rims, would be used in the enamelled set: 'White or coloured enamel, accentuated by shiny edging, makes an item more expressive. ${ }^{89}$

In addition to the kitchen tools, the prepared food was also supposed to be beautiful. Such items as vegetable or egg slicers (with thin wires for slicing) would make meals more aesthetically appealing, diversifying the domestic menu and, ultimately, stimulating healthy digestion. Of course, hygiene and economy, too, acted as important factors in design. Simple standardised plastic boxes with tight lids for storing different foodstuffs would impede the rotting or drying of food. Boxes for marinades would have square shapes with rounded corners for the convenience of washing. In the aluminium set, it would be technically impossible to put the teapot for brewing tea over the teapot for boiling water, as was customary in pre-revolutionary Russia and was still, evidently, practised by many in the 1960s. The project's authors characterised this method of tea-making as unhygienic, so the very forms of the designed items were meant to preclude it. Thus, the varieties offered appeared up-to-date in terms of materials, technologies, colour combinations and hygienic standards. This vision of up-to-date design was presumed to be universally applicable, regardless of aspects such as individual social behaviour, culinary habits, ethnic/cultural identities or aesthetic views. The designers' suggestion 


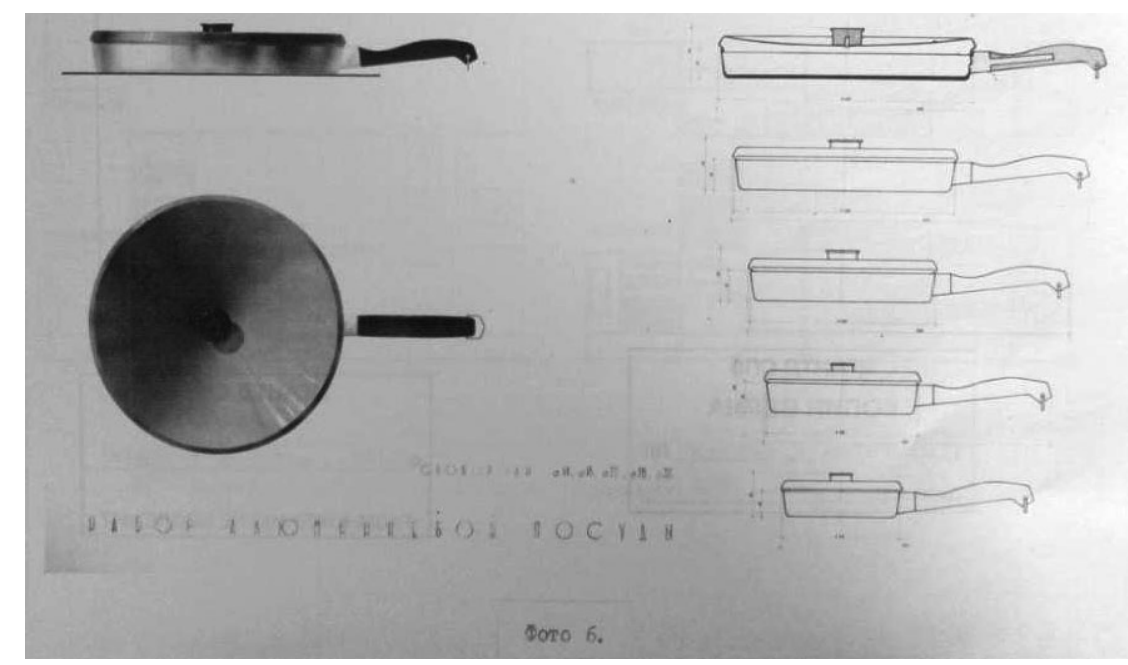

All rights reserved and permission to use the figure must be obtained from the copyright holder.

2.3 Vsevolod Medvedev et al., technical drawing of aluminium kitchenware, 1966.

of selling the kitchenware not only in sets but also as separate items 'to give consumers the opportunity to select sets according to their individual needs ${ }^{\prime} 90$ was a small step towards consumer flexibility.

However, the fourth stage of this KhKR was not successfully fulfilled. Medvedev's team envisioned that the set would be most in demand among the many new inhabitants of prefabricated flats and that, unlike current kitchenware items, the new ones would not go unsold. It was planned to produce a pilot lot of $3,000-5,000$ sets to more precisely determine the economic efficiency of these new varieties. ${ }^{91}$ The guidelines for putting the design into production were prepared by 1968 and sent to several Leningrad factories. ${ }^{92}$ The designers were ready to make compromises in terms of materials. However, the factories refused all their suggestions because they lacked the necessary materials and technological capabilities. The designers went to Vilnius and Kaunas in an attempt to establish agreements with local factories but found only limited success: the Kaunas factory Pirmunas agreed to select some pieces for production. Due to the failure to establish proper contracts with industry, Leningrad VNIITE discontinued work on these rational kitchenware sets.

Though the Leningrad kitchenware project never reached Soviet consumers, it can still be evaluated as having symbolic significance as an ultimate rejection of the chaos of forms. Unlike actually produced kitchenware that was in danger of going unused, VNIITE's shiny pots and pans with ergonomic handles, transparent containers for grain and colourful jars for tea and coffee remain as pure concepts of eternally relevant socialist objects, and as documents of the designers' painstaking attempts 
to harmonise everyday consumption. KhKR in general can be seen not as a utopian undertaking that was impossible to implement in a rigid planned economy, but as a particular mode of making sense of the multiplicity of Soviet objects and of creating hierarchies of things and uses - 'objectively defining the necessary and sufficient minimum of items, capable of providing a contemporary level of comfort' ${ }^{93}$ It was, therefore, an expressive element of what Serguei Oushakine calls 'Soviet productivism' - a cultural practice of late socialism that echoed the ideas of the 1920s theorists and focused on rationalising the relations between sensuous characteristics, forms and the social functions of things. ${ }^{94}$

\section{Conclusion}

By the mid-1950s the rapid changes in everyday life had brought architectural reform and the mass housing campaign, and revealed the great discrepancy between the production of consumer goods, consumer needs and the Soviet Union's aspiration to be an important participant in the development of modern culture and social policies internationally. On the level of material culture, this discrepancy revealed itself in the chaos of forms. While theorists were painstakingly developing a language to classify everyday objects, the state needed a smooth production of desirable commodities to fulfil its promises. Therefore, aesthetic considerations shrank to a modest component of a large, complex system of quality criteria that went far beyond the traditional realm of 'art'. Classifiable and evaluable things would become easily updatable objects, suitable to a limited variety of homes and tastes. A well-designed Soviet kitchen represented a seamless web of social, technical and aesthetic perfection that could be easily tailored to the tastes of a few social groups. However, this restrictive vision became outdated as soon as it appeared. As I will demonstrate in the following chapters, the order of Soviet things was doubted by its very creators.

\section{Notes}

1 A. Piletskii, 'Pribory i mebel', Dekorativnoe Iskusstvo SSSR 3 (1964), 24.

2 Ibid., 25.

3 This standard formulation, recurrent in Soviet official documents and press of the 1960s, first appeared at the XXIst Party Congress in 1959. 'Kontrol'nye tsifry razvitiia narodnogo khoziaistva na 1959-1965 gody', in Vneocherednoi XXI sezd kommunisticheskoi partii Sovetskogo Soiuza: 27 ianvaria-5 fevralia 1956 goda. Stenograficheskii otchet. Vol. 2 (Moscow: Gosudarstvennoe izdatelstvo politicheskoi literatury, 1959), pp. 456-549, 485.

4 Iurii Gerchuk, 'The Aesthetics of Everyday Life in the Khrushchev Thaw in the USSR (1954-64)', in Reid and Crowley (eds), Style and Socialism; Smith, Property of Communists; Harris, Communism on Tomorrow Street; Chernyshova, Soviet 
Consumer Culture in the Brezhnev Era; Varga-Harris, Stories of House and Home; Anna Alekseyeva, 'Constructing Soviet Domesticity and Managing Everyday Life from Khrushchev to Collapse', in Roberts (ed.), Material Culture in Russia and the USSR, pp. 55-70.

5 Denis Kozlov and Eleonory Gilburd, 'The Thaw as an Event in Russian History', in Denis Kozlov and Eleonory Gilburd, The Thaw: Soviet Society and Culture during the 1950s and 1960s (Toronto: University of Toronto Press, 2012), p. 44.

6 Ibid., p. 42.

7 Elizabeth A. St. Pierre, Alecia Y. Jackson, and Lisa A. Mazzei, 'New Empiricisms and New Materialisms: Conditions for New Inquiry', Cultural Studies $\leftrightarrow$ Critical Methodologies 16.2 (2016), 102, doi:10.1177/1532708616638694.

8 Ibid., 103.

9 Ibid., 104.

10 Bennett, Vibrant Matter, p. xvi.

11 Iurii Soloviev, 'O tekhnicheskoi estetike', Tekhnicheskaia Estetika 1 (1964), 1.

12 Cybernetics is an interdisciplinary field, founded by the American scientists Norbert Wiener, Warren Sturgis McCulloch and others in the late 1940s and focused on elaborating theories of control and communication in animal and machine behaviour.

13 West, 'CyberSovietica', p. 18.

14 Margareta Tillberg, 'Made in the USSR: Design of Electronic/Electrical Systems in the Soviet Union from Khruschev's Thaw to Gorbachev's Perestroika', Baltic Worlds 3.2 (2010), 38.

15 Tillberg, 'Made in the USSR', 261

16 Michel Foucault, The Order of Things: An Archaeology of the Human Sciences (New York: Vintage, 1994).

17 Martin Heidegger, 'The Thing', in Martin Heidegger, Poetry, Language, Thought (New York: HarperCollins, 1971), pp. 174-5.

18 Bill Brown, 'Thing Theory', Critical Inquiry 28.1 (2001), 4-5.

19 Bennett, Vibrant Matter, p. 5.

20 Moisei Kagan, 'O spetsifike i sushchnosti prikladnogo iskusstva', Iskusstvo 1 (1956), 16-21.

21 Ivan Matsa, 'Mozhet li mashina byt' proizvedeniiem iskusstva?' Dekorativnoe Iskusstvo SSSR 3 (1961), 14-16.

22 Matsa, 'Mozhet li mashina', 16

23 Tretiakov, 'Biografiia veshchi', 68-72.

24 Nikolai Tarabukin, Ot Mol'berta k mashine (Moscow: Rabotnik Prosveshcheniia, 1923), pp. 21-3.

25 A. Gorpenko, 'Iskusstvo I tekhnika', Dekorativnoe Iskusstvo SSSR 4 (1961), 25-7.

26 Ibid., 26

27 Ibid., 27.

28 B. Shragin, 'Protiv privychnykh predstavlenii', Dekorativnoe Iskusstvo SSSR 5 (1961), 26-7.

29 K. Kantor, 'Gde zhe granitsa prikladnogo iskusstva?' Dekorativnoe Iskusstvo SSSR 6 (1961), 21-3.

30 IU. Gerchuk, 'Mashina kak proizvedeniie promyshlennogo iskusstva', Dekorativnoe Iskusstvo SSSR 2 (1962), 31-3.

31 'K itogam diskussii: 'mozhet li mashina byt' proizvedeniiem prikladnogo iskusstva?', Dekorativnoe Iskusstvo SSSR 12 (1962), 23-4, 45.

32 Ibid., 23.

33 Ibid., 24.

34 See interviews with former VNIITE designers conducted by the curators of the Moscow Design Museum in 2012 on the museum's YouTube channel, www.you tube.com/user/MoscowDesignMuseum (accessed 2 August 2019). Irina Kostenko, 
director of VNIITE's design centre that operated from 1975, shared a memory of 'design' as a strictly forbidden word at the conference '(De)Constructing Utopia: Design in Eastern Europe from Thaw to Perestroika', Sheffield University, 2-3 May 2014

35 Larisa Zhadova, 'O terminogogii i poniatiakh v sfere promyshlennogo iskusstva', Tekhnicheskaia Estetika 7 (1964), 14-17.

36 TsGALI SPb, f. 7, op. 1, d. 38.

37 Runge, Istoriia dizaina, nauki i tekhniki, p. 285.

38 RGALI, f. 2460, op. 2, d. 220.

39 Runge, Istoriia dizaina, nauki i tekhniki, p. 285.

40 Zhadova, 'O terminogogii i poniatiakh v sfere promyshlennogo iskusstva', 15-16; Mikhail Kos'kov, interview with the author, recorded in St Petersburg on 16 April 2011.

41 Khan-Magomedov, Pionery sovetskogo dizaina, p. 383.

42 Although it was not mentioned by Zhadova in her talk, the term khudozhestvennoe konstruirivaie was sometimes used by the constructivists in the 1920s. See Lodder, Russian Contructivism.

43 Zhadova, 'O terminogogii i poniatiakh v sfere promyshlennogo iskusstva', 14-17.

44 Russian State Archive of Scientific and Technical Documentation, Moscow (hereafter RGANTD), f. R-688, op. 1-1, d. 57, 1. 21. I am thankful to Tom Cubbin for sharing the archival location of this document.

45 David Raizman, History of Modern Design: Graphics and Products since the Industrial Revolution (London: Laurence King Publishing, 2003).

46 Simon Bojko, 'Na tretiem kongresse IKSIDa', Dekorativnoe Iskusstvo SSSR 11 (1963), 23-48; 'Un esprit de l'Industrial design? Icsid Paris 1963', Design et Histories, Le blog de Jocelyne Leboeuf, 6 January 2013, http://blogs.lecolededesign.com/design ethistoires/2013/01/06/un-esprit-de-lindustrial-design-icsid-paris-1963/ (accessed 10 December 2017).

47 Evgenii Rozenblium, 'Problemy dizaina', Dekorativnoe Iskusstvo SSSR 1 (1966), 2-5.

48 Raizman, History of Modern Design, p. 240.

49 Soloviev, 'O tekhnicheskoi estetike', 2.

50 Raizman, History of Modern Design, p. 240.

51 G. Liubimova, 'Veshchi v dome', Dekorativnoe Iskusstvo SSSR 8 (1965), 2-5.

52 Ia. Orlov, 'Tsena plokhogo kachestva', Tekhnicheskaia Estetika 1 (1964), 27-9.

53 RGANTD, f. R-688, op. 1-1, d. 57, 1. 4.

54 RGANTD, f. R-688, op. 1-1, d. 57, ll. 5-8.

55 RGANTD, f. R-688, op. 1-1, d. 57, ll. 24-5.

56 Aleksandr Riabushin, 'Zadachi i sposoby opredeleniia bytovogo oborudovaniia', Tekhnicheskaia Estetika 6 (1966), 3-5.

57 Anatolii Piskoppel', 'G. P. Shchedrovitskii - podvizhnik i myslitel', in N. I. Kuznetsova (ed.), Poznaiushchee myshleniie i sotsial'noe deistviie. Naslediie G. P. Shchedrovitskogo $v$ kontekste otechestvennoi i mirovoi sotsial'noi mysli (Moscow: F. A. S.-media, 2004), 24-4.

58 Reid, 'Khrushchev Modern', 251.

59 Literary critic and journalist Aleksandr Arkhangel'skii outlined in a public lecture on Soviet philosophy that the establishment of an institute was a matter of chance. Grushin, a graduate of the Philosophy Department of Moscow State University, could not find a position in research or teaching because of his difficult character and thus ended up as the head of the department of readers' letters of Komsomol'skaia Pravda. Thus, he devised an institute of public opinion as an outlet for his intellectual ambitions. Arkhangel'skii probably drew the information about Grushin's personality from informal communications with Grushin himself (who was thirty-three years older and died in 2003) or his colleagues or pupils. Aleksandr Arkhangel'skii, 'Nesovetskaia filosophiia v SSSR' (online course), 
educational website Arzamas, 5 March 2015, http://arzamas.academy/courses/1/2 (accessed 25 January 2018).

60 Boris Grushin, 'Institut obshchestvennogo mneniia 'Komsomol'skoi Pravdy', Monitoring obshchestvennogo mneniia 1.63 (January-February 2003), https://cyber leninka.ru/article/v/institut-obschestvennogo-mneniya-komsomolskoy-pravdy (accessed 25 January 2017).

61 Foreign sources for the methods of consumer research are listed in the VNIITE report from 1965: RGANTD, f. R-688, op. 1-1, d. 122, 1. 37.

62 V. Shvili, 'Chto daiut konkretno-sotsiologicheskie issledovaniia promyshlennosti I torgovle', Tekhnicheskaia Estetika 2 (1965), 1-2.

63 Ibid., 2.

64 Serguei A. Oushakine suggests translating the institute's exact name as the AllUnion Research Institute for the Study of Popular Demands for Commodities of Popular Consumption, and of Commerce (Vsesoiuznyi nauchno issledovatel'skii institut po izucheniiu sprosa naseleniia na tovary narodnogo potrebleniia i kon'iuktury torgovli, VNIIKS).

65 Serguei Alex Oushakine, “"Against the Cult of Things”: On Soviet Productivism, Storage Economy, and Commodities with No Destination', Russian Review 73.2 (2014), 251.

66 Chernyshova, Soviet Consumer Culture in the Brezhnev Era, p. 26.

67 RGANTD, f. R-688, op. 1-1, d. 122.

68 RGANTD, f. R-688, op. 1-1, d. 122, 1. 11.

69 RGANTD, f. R-688, op. 1-1, d. 122, 1. 13-36.

70 RGANTD, f. R-688, op. 1-1, d. 122, ll. 11, 40.

71 RGANTD, f. R-688, op. 1-1, d. 85.

72 Metodicheskie ukazaniia po provedeniiu ekspertizy promyshlennykh izdelii s pozitsii tekhnicheskoi estetiki (Moscow: VNIITE, 1967), pp. 5-6.

73 Ibid., p. 14.

74 Programmema Kommunisticheskoi partii Sovetskogo Soiuza (Moscow: Politizdat, 1961), http://museumreforms.ru/node/13891 (accessed 13 April 2018).

75 V. A. Nesterov and A. Ia. Kovalev (eds), Arkhitektura: Raboty proektnykh i nauchnykh institutov Moskvy 1966-1969 (Moscow: Stroiizdat, 1970), p. 169, cited in Cubbin, 'The Domestic Information Machine', 25.

76 RGANTD, f. R-688, op. 1-1, d. 122, ll. 11, 40-1.

77 Metodicheskie ukazaniia, pp. 14-18.

78 RGANTD, f. R-688, op. 1-1, d. 181. I am thankful to Tom Cubbin for sharing the archival location of this document.

79 Central State Archive of Scientific and Technical Documentation, St Petersburg (hereafter TsGANTD SPb), f. 146, op. 2-1, d. 78, ll. 13-16.

80 Kos'kov, Predmetnoe tvorchestvo, pp. 11-12.

81 West, 'CyberSovietica', p. 152.

82 TsGANTD SPb, f. 146, op. 2-1, d. 77.

83 Nicholas Bullock, 'First the Kitchen: Then the Façade', Journal of Design History 1.3/4 (1988), 177-92; Ruth Schwartz Cowan, More Work for Mother: The Ironies of Household Technology from the Open Hearth to the Microwave (New York: Basic Books, 1983); Ghislane Hermanuz, 'Outgrowing the Corner of the Kitchen Table', in Joan Rothschild and Alethea Cheng (eds), Design and Feminism: Re-Visioning Spaces, Places, and Everyday Things (New Brunswick, NJ: Rutgers University Press, 1999), pp. 67-84; Victoria de Grazia, Irresistible Empire: America's Advance through Twentieth-Century Europe (Cambridge, MA: Belknap Press of Harvard University Press, 2006); Susan E. Reid, 'The Khrushchev Kitchen: Domesticating the Scientific-Technological Revolution', Journal of Contemporary History 40.2 (2005), 289-316.

84 Ruth Oldenziel and Karen Zachmann, 'Introduction', in Ruth Oldenziel and Karin 
Zachmann (eds), Cold War Kitchen: Americanization, Technology, and European Users (Cambridge, MA: MIT Press, 2011), pp. 1-32.

85 RGANTD, f. 281, op. 1-1, ed. khr. 85, 'Social-Economic Research of Consumer Demands to the Tools Mechanizing Domestic Labor', December 1965.

86 Aleksandr Riabushin, 'Zhilishche novogo tipa', Dekorativnoe Iskusstvo SSSR 2 (1963), 5-10.

87 The results of the second stage of the KhKR were presented in the press: V. Medvedev, 'Assortiment kukhonnoi posudy', Tekhnicheskaia Estetika 6 (1966), 13-17.

88 TsGANTD SPb, f. 146, op. 2-1, d. 77, 1. 36. Unfortunately, the archival file of this KhKR includes only black-and-white illustrations.

89 TsGANTD SPb, f. 146, op. 2-1, d. 77, 1. 39.

90 TsGANTD SPb, f. 146, op. 2-1, d. 77, 1. 58.

91 TsGANTD SPb, f. 146, op. 2-1, d. 77, 1. 61.

92 TsGANTD SPb, f. 146, op. 2-1, d. 79.

93 Riabushin, 'Zadachi i sposoby', 3.

94 Oushakine, 'Against the Cult of Things'. 